Received: September 18, 2008

Accepted after revision: February 9, 2009

Published online: September 4, 2009

\title{
Nitric Oxide Suppresses Cerebral Vasomotion by sGC-Independent Effects on Ryanodine Receptors and Voltage-Gated Calcium Channels
}

\author{
Kathryn H. Yuill ${ }^{\mathrm{a}}$ Alister J. McNeish ${ }^{\mathrm{a}}$ Yasuo Kansui ${ }^{\mathrm{a}}$ Christopher J. Garland ${ }^{\mathrm{b}}$ \\ Kim A. Dora ${ }^{b}$ \\ ${ }^{a}$ Department of Pharmacy and Pharmacology, University of Bath, Bath, and ${ }^{\mathrm{b}}$ Department of Pharmacology, \\ University of Oxford, Oxford, UK
}

\section{Key Words}

Nitric oxide $\cdot$ Membrane potential $\cdot$ Calcium signalling $\cdot$ Vascular smooth muscle $\cdot$ Cerebral arteries $\cdot$ Vasomotion

\begin{abstract}
Background/Aims: In cerebral arteries, nitric oxide (NO) release plays a key role in suppressing vasomotion. Our aim was to establish the pathways affected by NO in rat middle cerebral arteries. Methods: In isolated segments of artery, isometric tension and simultaneous measurements of either smooth muscle membrane potential or intracellular $\left[\mathrm{Ca}^{2+}\right]$ $\left(\left[\mathrm{Ca}^{2+}\right]_{S M C}\right)$ changes were recorded. Results: In the absence of L-NAME, asynchronous propagating $\mathrm{Ca}^{2+}$ waves were recorded that were sensitive to block with ryanodine, but not nifedipine. L-NAME stimulated pronounced vasomotion and synchronous $\mathrm{Ca}^{2+}$ oscillations with close temporal coupling between membrane potential, tone and $\left[\mathrm{Ca}^{2+}\right]_{S M C}$. If nifedipine was applied together with L-NAME, $\left[\mathrm{Ca}^{2+}\right]_{S M C}$ decreased and synchronous $\mathrm{Ca}^{2+}$ oscillations were lost, but asynchronous propagating $\mathrm{Ca}^{2+}$ waves persisted. Vasomotion was similarly evoked by either iberiotoxin, or by ryanodine, and to a lesser extent by ODQ. Exogenous application of NONOate stimulated endothelium-independent hyperpolarization and relaxation of either L-NAME-induced or spontaneous arterial tone. NO-evoked hyperpolarization involved
\end{abstract}

activation of $\mathrm{BK}_{\mathrm{Ca}}$ channels via ryanodine receptors (RYRs), with little involvement of sGC. Further, in whole cell mode, NO inhibited current through L-type voltage-gated $\mathrm{Ca}^{2+}$ channels (VGCC), which was independent of both voltage and sGC. Conclusion: NO exerts sGC-independent actions at RYRs and at VGCC, both of which normally suppress cerebral artery myogenic tone.

Copyright $\odot 2009$ S. Karger AG, Basel

\section{Introduction}

Cerebral arteries typically display spontaneous, submaximal constriction that is dependent on the level of intraluminal pressure or isometric stretch, termed myogenic tone. This myogenic tone is an essential mechanism in the local control of blood flow and tissue perfusion in the cerebral vasculature both in vivo and in vitro, and in many other vascular beds $[1,2]$. The development of myogenic tone is generally characterized by vascular smooth muscle cell depolarization, leading to an increase in intracellular $\left[\mathrm{Ca}^{2+}\right]\left(\left[\mathrm{Ca}^{2+}\right]_{\mathrm{SMC}}\right)$ and associated constriction of the artery $[1,3]$. Myogenic responses, by definition, can occur without a functional endothelial cell layer; how-

K.H.Y. and A.J.M. contributed equally to this paper.

\section{KARGER}

Fax +41613061234 E-Mail karger@karger.ch www.karger.com

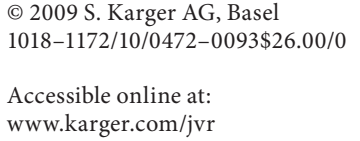

Dr. Kim Dora

Department of Pharmacology, University of Oxford

Mansfield Rd

Oxford OX1 3QT (UK)

Tel. +44 1865271 850, Fax +44 1865271 853, E-Mail kim.dora@pharm.ox.ac.uk 
ever, the endothelium can considerably modulate the degree of myogenic tone by releasing a number of factors including nitric oxide (NO), prostacyclin and endothelium-derived hyperpolarizing factor.

In addition to suppressing myogenic tone, endothelium-derived factors also modulate the vasomotion that often occurs in tandem with the development of myogenic constriction. Vasomotion describes rhythmic oscillations in tension or diameter that are normally synchronous with oscillations in $\mathrm{Ca}^{2+}$ and membrane potential $\left(\mathrm{E}_{\mathrm{m}}\right)$. In the brain, oscillations in middle cerebral artery blood flow velocity (as a result of vasomotion) have been observed in many species, including humans [4] and rats [5]. The role of the endothelium in the control of vasomotion is unclear; in some vascular beds the $\mathrm{NO} /$ cGMP pathway has been shown to augment vasomotion [6]. However, in other beds, including the cerebral vasculature $[5,7], \mathrm{NO} / \mathrm{cGMP}$ attenuates this response as NO synthase (NOS) inhibitors stimulate vasomotion. This vasomotion manifests as a reduction in capillary blood flow, which tends to oscillate in synchrony within the bed [8]. Therefore, any disruption of the ability to synthesize NO can potentially lead to vasomotion and/or spasm, as observed under pathophysiological conditions such as subarachnoid haemorrhage $[9,10]$.

In arteries isolated from both coronary $[11,12]$ and cerebral [13-20] beds, a continual, basal release of NO suppresses myogenic tone, with inhibition of NOS leading to depolarization and constriction in the absence of vasoconstrictor agents. NO can either stimulate hyperpolarization and closure of voltage-gated $\mathrm{Ca}^{2+}$ channels (VGCC), or directly close VGCC, both of which suppress myogenic tone. In terms of hyperpolarization, NO can activate smooth muscle cell $\mathrm{BK}_{\mathrm{Ca}}$ channels either directly [21-23] or via PKG-dependent mechanisms [24, 25]. NO can also stimulate ryanodine-sensitive calcium stores (by opening the ryanodine receptor, RYR) in the sarcoplasmic reticulum, evoking discrete calcium events termed 'sparks' that activate adjacent clusters of $\mathrm{BK}_{\mathrm{Ca}}$ channels. This mechanism has been suggested to underpin NO-dependent relaxation in the rat posterior cerebral artery [26] where the presence of NO is reported to be a prerequisite to activate the RYRs. Stimulation of RYRs by NO could be either direct or indirect, such as nitrosylation of thiol groups [27], or via cGMP-mediated phosphorylation of the channel and the sarcoplasmic reticulum calcium ATPase [28], respectively. In addition, NO can close VGCC in a membrane potential-independent manner, which can occur either via sGC/PKG [29-31] and/or by nitrosylation [32-34].
Therefore, we investigated further the mechanisms underlying the modulation of myogenic tone and the development of vasomotion associated with the basal release of NO in the rat (middle) cerebral arteries. Although our data support the suggestion that NO does stimulate RYR channels to release calcium that drives $\mathrm{BK}_{\mathrm{Ca}}$ channel-mediated hyperpolarization, they also suggest 2 further important aspects of NO activity. First, that inhibition of NOS masks (rather than inhibits) spontaneous oscillations in smooth muscle cell calcium due to activation of VGCCs and the appearance of vasomotion, which is consistent with activation of RYRs via NO-independent pathways. Second, a direct inhibitory action of $\mathrm{NO}$ on VGCCs can suppress cerebral artery myogenic tone.

\section{Materials and Methods}

Male Wistar rats (200-300 g) were euthanized using procedures defined by the Animals (Scientific Procedures) Act 1986, UK (schedule 1 procedure) and the brain was rapidly removed and stored immediately in ice-cold physiological salt solution for a maximum of $30 \mathrm{~min}$.

\section{Simultaneous Measurement of Tension and Membrane}

Potential

A 2-mm segment of the middle cerebral artery (internal diameter of approx. $175 \mu \mathrm{m}$ ) was mounted in a Mulvany-Halpern myograph (model 410A; Danish Myotechnology) in Krebs solution containing (in $\mathrm{mM}$ ): $\mathrm{NaCl}, 118.0 ; \mathrm{NaCO}_{3}, 25 ; \mathrm{KCl}, 3.6 ; \mathrm{MgSO}_{4}$ $7 \mathrm{H}_{2} \mathrm{O}, 1.2 ; \mathrm{KH}_{2} \mathrm{PO}_{4}, 1.2 ;$ glucose, $11.0 ; \mathrm{CaCl}_{2}, 2.5$; and gassed with $95 \% \mathrm{O}_{2}$ and $5 \% \mathrm{CO}_{2}$ at $37^{\circ} \mathrm{C}$. The vessels were allowed to equilibrate for $20 \mathrm{~min}$ and were then tensioned to $1-1.5 \mathrm{mN}$ (approximates wall tension at $60 \mathrm{~mm} \mathrm{Hg}$ ). Vessel viability was assessed by the addition of exogenous $\mathrm{K}^{+}(15-55 \mathrm{mM})$, only vessels developing tension $\geq 3 \mathrm{mN}$ were used. Endothelial cell viability was assessed by the ability of SLIGRL ( $20 \mu \mathrm{M}$; a protease-activated receptor 2 ligand) to relax U46619-induced tone by $>70 \%$ and to hyperpolarize the smooth muscle cell membrane by $>15 \mathrm{mV}$. All blocking drugs were allowed to equilibrate for $20 \mathrm{~min}$ before study except nifedipine and ryanodine which produced immediate responses or whose effects were studied over a 20 -min period. In some experiments, endothelial cells were removed by gently rubbing the luminal surface with a human hair; subsequent relaxation of $<15 \%$ to SLIGRL $(20 \mu \mathrm{M})$ was considered as successful removal. Smooth muscle cell tension and $\mathrm{E}_{\mathrm{m}}$ were measured simultaneously as previously described [35] and were recorded with the use of Powerlab system (AD Instruments). Briefly, individual smooth cells were impaled with a glass electrode (filled with $2 \mathrm{M} \mathrm{KCl}$, tip resistance $60-100 \mathrm{M} \Omega$ ) held perpendicular to the cells.

Simultaneous Measurement of Changes in $\left[\mathrm{Ca}^{2+}\right]_{S M C}$ and

Tension

A segment of middle cerebral artery was mounted as described above except in a Mulvany-Halpern myograph designed for use on a confocal microscope (model 120CW; Danish Myotechnology) and in MOPS buffer containing (in $\mathrm{mM}$ ): $\mathrm{NaCl}, 145 ; \mathrm{KCl}, 4.7$; 
$\mathrm{CaCl}_{2}, 2.0 ; \mathrm{MgSO}_{4}, 1.17$; MOPS, 2.0; $\mathrm{NaH}_{2} \mathrm{PO}_{4}$, 1.2; glucose, 5.0; pyruvate, 2.0; EDTA, $0.02 ; \mathrm{NaOH}, 2.75$ (the $\mathrm{pH}$ of the solution was adjusted to $7.39-7.41$ at $37^{\circ} \mathrm{C}$ using $\mathrm{NaOH}$ or $\mathrm{HCl}$, as appropriate). The arteries were loaded with the calcium-sensitive fluorescent dye Oregon Green 488 BAPTA-1 AM [10 $\mu \mathrm{M}$; dissolved in DMSO and $0.02 \%(\mathrm{w} / \mathrm{v})$ Pluronic F-127] for $1 \mathrm{~h}$. After excitation at 488 $\mathrm{nm}$, the fluorescence emission intensity at $515 \mathrm{~nm}$ was recorded using a spinning disc confocal microscope (Yokogawa CSU22) fitted with an Andor iXON DV887ECS-BV camera mounted on an Olympus IX70 inverted microscope using a water immersion objective ( $\times 40$, aperture 0.8 , working distance $3.3 \mathrm{~mm}$; Olympus) and images $(512 \times 512$ pixels, $20 \mathrm{~Hz})$ were stored for offline analysis (iQ; Andor). Following background subtraction, average relative changes in $\left[\mathrm{Ca}^{2+}\right]_{S M C}$ were calculated as changes in intensity of fluorescence divided by fluorescence at time $0 \mathrm{~s}\left(\mathrm{~F} / \mathrm{F}_{0}\right)$, within selected cell regions $(5 \times 5$ pixels $)$.

\section{Isolated Smooth Muscle Cell Patch Clamp Experiments}

Freshly dissected middle cerebral arteries were placed in icecold $\mathrm{Ca}^{2+}$-free isolation solution containing (in $\mathrm{mM}$ ): $\mathrm{NaCl}, 140$; $\mathrm{KCl}, 4.7 ; \mathrm{MgCl}_{2}, 1.2$; glucose, 10; HEPES, 10 (pH 7.4). After incubation on ice for $20 \mathrm{~min}$, the arteries were transferred to $\mathrm{Ca}^{2+}$-free isolation solution, containing $1 \mathrm{mg} / \mathrm{ml}$ albumin, $1 \mathrm{mg} / \mathrm{ml}$ papain (Sigma) and $1 \mathrm{mg} / \mathrm{ml}$ dithiothreitol, and allowed to digest for 20 $\min$ at $37^{\circ} \mathrm{C}$. The tissue was then transferred into a solution containing $0.1 \mathrm{mM} \mathrm{CaCl}_{2}$ and $1 \mathrm{mg} / \mathrm{ml}$ collagenase type $\mathrm{H}$ (Roche) plus $1 \mathrm{mg} / \mathrm{ml}$ collagenase type $\mathrm{F}$ (Sigma). Following digestion for $10 \mathrm{~min}$ at $37^{\circ} \mathrm{C}$, the tissue was washed in isolation solution containing $1 \mathrm{mg} / \mathrm{ml}$ albumin and $0.1 \mathrm{mM} \mathrm{CaCl}_{2}$. After gentle trituration, cells were centrifuged for $5 \mathrm{~min}$ at $1,000 \mathrm{rpm}$, the supernantant removed, and resuspended in fresh isolation solution. The concentration of extracellular calcium was increased over the next $30 \mathrm{~min}$ to $750 \mu \mathrm{M}$. Freshly isolated cells were maintained on ice for use on the same day.

Cells were placed in a heated recording chamber (RC-25F; Warner Instruments) and left for approximately $10 \mathrm{~min}$ to adhere to the cover glass. Cells were then continually superfused (approx. $1 \mathrm{ml} / \mathrm{min}$ ) with heated solution (SH-27B Inline Heater; Warner Instruments) via a multi-barrel gravity-fed perfusion system. Experiments were performed using an agar bridge (2\% agar filled with $3 \mathrm{M} \mathrm{KCl}$ ). During seal formation, cells were superfused with physiological saline solution containing (in $\mathrm{mM}$ ): $\mathrm{NaCl}, 140 ; \mathrm{KCl}$, $4 ; \mathrm{CaCl}_{2}, 1.5 ; \mathrm{MgCl}_{2}, 1.2 ; \mathrm{HEPES}, 10$; glucose, $10 ; \mathrm{pH}$ 7.4. To record membrane potential, the pipette solution contained (in $\mathrm{mM}$ ): $\mathrm{KCl}$, 130; $\mathrm{NaCl}, 10 ; \mathrm{HEPES}, 10 ; \mathrm{MgCl}_{2}, 0.5 ; \mathrm{CaCl}_{2}, 0.5 ;$ Amphotericin $\mathrm{B}(200 \mu \mathrm{g} / \mathrm{ml})$. To record L-type calcium current $\left(\mathrm{I}_{\mathrm{CaL}}\right)$, the whole cell mode was used and $\mathrm{Ba}^{2+}$ was used as the charge carrier. Cells were perfused with solution containing (in $\mathrm{mM}$ ): $\mathrm{NaCl}, 120 ; \mathrm{CsCl}$, 4; TEA-Cl, 10; $\mathrm{BaCl}_{2}, 10 ; \mathrm{MgCl}_{2}, 1.2$; HEPES, 10; glucose; $\mathrm{pH}$ 7.4. The pipette solution contained (in $\mathrm{mM}$ ): $\mathrm{CsCl}, 130 ; \mathrm{MgCl}_{2}, 0.4$; HEPES, 10; EGTA 2; $\mathrm{CaCl}_{2}$, 0.4; GTP, 0.5; MgATP, 5; pH 7.3. The osmolarity of all solutions was measured and corrected to $300 \pm$ 5 mOsm using mannitol. All electrophysiological recordings were performed at $37^{\circ} \mathrm{C}$.

$\mathrm{I}_{\mathrm{CaL}}$ was recorded using a 1-second ramp protocol, from -100 to $+80 \mathrm{mV}$ from a holding potential of $-80 \mathrm{mV}$ at a frequency of $0.05 \mathrm{~Hz}$. Nifedipine $(1 \mu \mathrm{M})$ was applied at the end of the protocol and subtracted from the current records obtained in barium-containing solution, and the data presented as nifedipine-sensitive current. Cell membrane capacitance was measured using a $10-\mathrm{mV}$ hyperpolarizing step and used to correct $\mathrm{I}_{\mathrm{CaL}}$ currents for cell size. Currents were expressed as current density $(\mathrm{pA} / \mathrm{pF})$. Any cell exhibiting current rundown in control conditions was excluded from the analysis. NONOate was freshly diluted with physiological saline solution, and infused via an injection port in the superfusion line directly upstream from the recording chamber. In experiments with the sGC inhibitor $1 \mathrm{H}-(1,2,4)$ oxadiazolo $(4,3-\mathrm{a})$ quinoxalin-1-one (ODQ), cells were incubated in $10 \mu \mathrm{M}$ ODQ for $15 \mathrm{~min}$, and it was also included in the perfusion solutions.

Data were analyzed and leak subtracted offline using pClamp 8 (Axon Instruments). Values are expressed as means \pm SEM of $\mathrm{n}$ cells (from at least 3 animals). The paired two-tail t test was used to compare parameters obtained in control and test conditions in the same cell. A non-paired t test was used to compare the differences between groups of data.

\section{Solutions and Drugs}

Exogenous $\mathrm{K}^{+}$was added as an isotonic solution, and expressed as the final bath concentration. Caffeine, $\mathrm{N}^{\mathrm{G}}$-nitro-L-arginine methyl ester (L-NAME), nifedipine, ryanodine, BayK 8644 and papaverine were all obtained from Sigma. Iberiotoxin (IbTx) was obtained from Latoxan; DEA-NONOate from Alexis; ODQ from Tocris; SLIGRL from Auspep; Oregon Green 488 BAPTA-AM from Molecular Probes; TRAM-34 was a gift from Dr. H. Wulff (University of California, Davis, Calif., USA); U46619 was obtained from Calbiochem. All drugs were made in $0.9 \% \mathrm{NaCl}$ except ryanodine, nifedipine, ODQ, U46619 and Amphotericin B in DMSO; NONOate in $0.01 \mathrm{M} \mathrm{NaOH}$ (and stored at $-80^{\circ} \mathrm{C}$ ), and (-) BayK 8644 in EtOH. All subsequent dilutions of all drugs were made in $0.9 \% \mathrm{NaCl}$ and vehicle had no effect. NONOate dilutions were kept on ice in the dark and were discarded after $20 \mathrm{~min}$.

\section{Statistical Analysis}

Results are expressed as the mean \pm SEM of $\mathrm{n}$ animals. Relaxation is expressed as the peak percentage reduction of the total vascular tone (from the myogenic tone to the tension/diameter following addition of papaverine, $150 \mu \mathrm{M}$ ) or as $\mathrm{mN}$, as appropriate. Constriction is expressed in $\mathrm{mN}$ or as a percentage of maximal constriction induced by exogenous $\mathrm{K}^{+}(55 \mathrm{~mm})$, as appropriate; all values were the peak values. When oscillations in membrane potential or tension were observed, values are the average of $10 \mathrm{~s}$. Graphs were drawn and statistical comparisons made using either Student's t test or one-way ANOVA with Tukey's or Dunnett's post hoc test using Prism software (Graphpad).

\section{Results}

\section{Effect of Inhibiting NOS, $s G C, R Y R s$ and $B K_{C a}$ Channels on Myogenic Tone}

Rat middle cerebral arteries exhibit myogenic tone in a wire myograph equivalent to approximately $15 \%$ of the maximum tension the vessel can develop [18], and associated with a resting membrane potential $\left(\mathrm{E}_{\mathrm{m}}\right)$ of $-50 \pm 0.2$ $\mathrm{mV}(\mathrm{n}=9)$. Addition of the NOS inhibitor L-NAME $(100$ $\mu \mathrm{M}$ ) evoked depolarization (to $\mathrm{E}_{\mathrm{m}}-43.7 \pm 1.9 \mathrm{mV}, \mathrm{n}=6$ ) and constriction (increase in tension of $3.7 \pm 0.5 \mathrm{mN}$, 


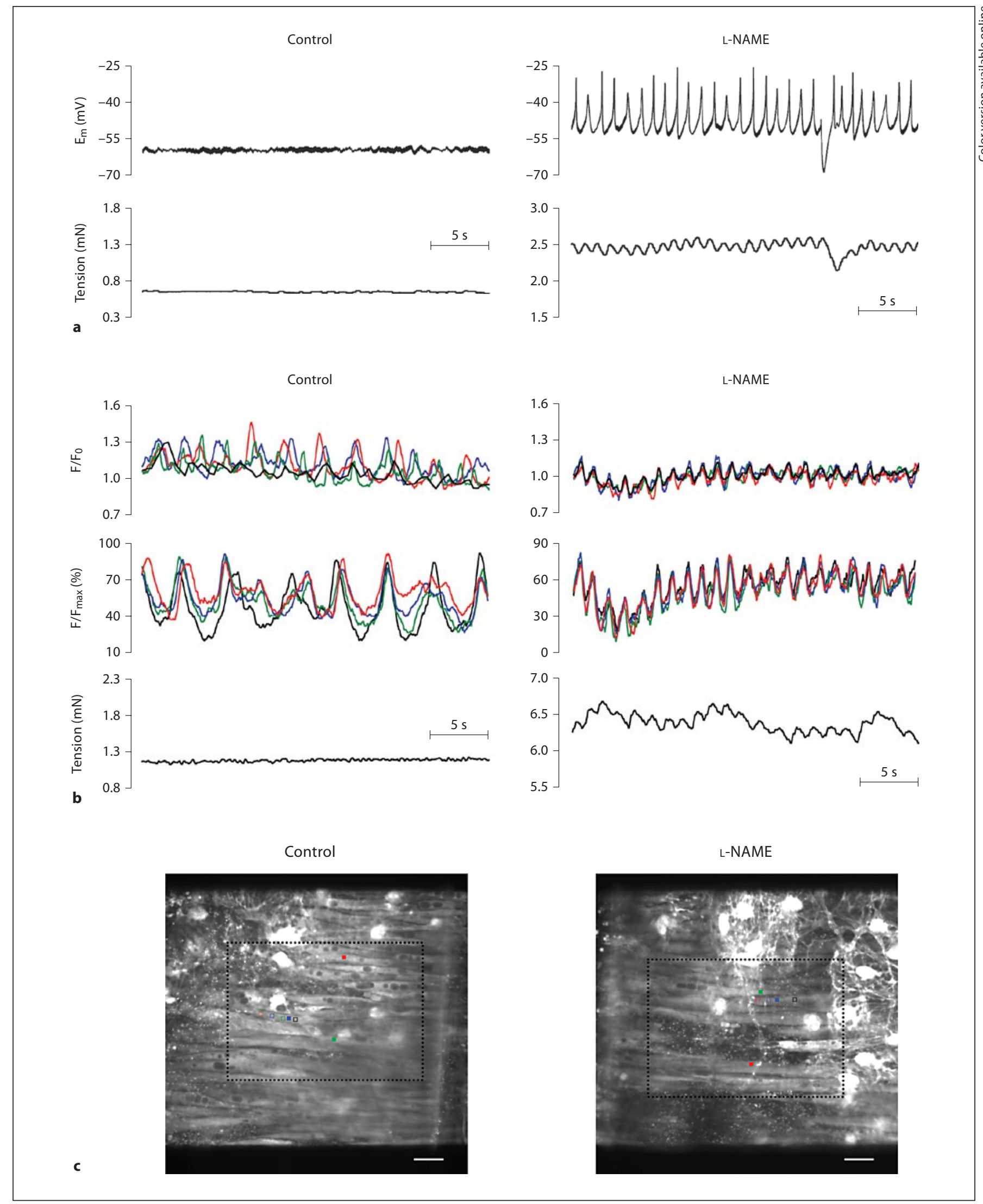


Table 1. Amplitude and frequency of smooth muscle cell $\mathrm{E}_{\mathrm{m}}$, tension and synchronous $\mathrm{Ca}^{2+}$ oscillations

\begin{tabular}{|c|c|c|c|c|c|c|}
\hline & \multicolumn{4}{|c|}{ Smooth muscle cell $\mathrm{E}_{\mathrm{m}}$} & \multirow{2}{*}{\multicolumn{2}{|c|}{$\begin{array}{l}{\left[\mathrm{Ca}^{2+}\right]_{\mathrm{SMC}}} \\
\text { oscillation frequency }\end{array}$}} \\
\hline & \multicolumn{2}{|c|}{ oscillation amplitude } & \multicolumn{2}{|c|}{ oscillation frequency } & & \\
\hline & $\mathrm{E}_{\mathrm{m}}, \mathrm{mV}$ & tension, $\mathrm{mN}$ & $\mathrm{E}_{\mathrm{m}}, \mathrm{Hz}$ & tension, $\mathrm{Hz}$ & $\mathrm{Ca}^{2+}, \mathrm{Hz}$ & tension, $\mathrm{Hz}$ \\
\hline L-NAME & $16.4 \pm 1.8$ & $0.14 \pm 0.2$ & $0.85 \pm 0.06$ & $0.84 \pm 0.05$ & $0.75 \pm 0.05$ & $0.76 \pm 0.04$ \\
\hline IbTx & $19.7 \pm 2.3$ & $0.11 \pm 0.02$ & $0.97 \pm 0.05$ & $0.96 \pm 0.06$ & ND & ND \\
\hline ODQ & $8.1 \pm 0.7^{*}$ & $0.13 \pm 0.02$ & $0.57 \pm 0.06^{*}$ & $0.56 \pm 0.07^{*}$ & ND & ND \\
\hline Ryanodine & $19.5 \pm 3.4$ & $0.06 \pm 0.01^{*}$ & $1.08 \pm 0.06$ & $1.06 \pm 0.06$ & $1.04 \pm 0.04^{*}$ & $1.01 \pm 0.05^{*}$ \\
\hline
\end{tabular}

Data are expressed as means \pm SEM $(\mathrm{n}=4-11)$. Time-matched, paired values were obtained from simultaneous records of either $\mathrm{E}_{\mathrm{m}}$ and tension or $\mathrm{Ca}^{2+}$ and tension. $\mathrm{ND}=$ Not determined. ${ }^{*} \mathrm{p}<0.05$ significant difference from L-NAME.

$\mathrm{n}=7$; fig. 1). In addition, oscillations in $\mathrm{E}_{\mathrm{m}}$ developed, temporally linked to oscillations in tension (fig. 1; table 1). Fluorescence imaging revealed that in unstimulated control arteries, smooth muscle cells displayed spontaneous and asynchronous propagating $\mathrm{Ca}^{2+}$ waves (172 of 210 cells; fig. 1; online supplementary video 1, www.karger.com/doi/10.1159/000235964). The oscillations occurred with a frequency of $0.27 \pm 0.02 \mathrm{~Hz}(\mathrm{n}=$ 21; table 1) and were not associated with any change in tension (fig. 1). Addition of L-NAME increased the glob-

Fig. 1. Spontaneous NO release prevents vasomotion. Original traces showing simultaneous recordings of membrane potential $\left(\mathrm{E}_{\mathrm{m}}\right)$ and tension $(\mathbf{a})$ or simultaneous recordings of $\left[\mathrm{Ca}^{2+}\right]_{\mathrm{SMC}}(2$ upper panels) and tension (b) under control resting conditions or in the presence of the NOS inhibitor L-NAME $(100 \mu \mathrm{M})$ in rat middle cerebral arteries. Under control conditions, membrane potential and tension are relatively stable, and at the same time, $\left[\mathrm{Ca}^{2+}\right]_{\text {SMC }}$ is constantly oscillating, but these oscillations are asynchronous between smooth muscle cells and can be observed as waves passing along cells (asynchronous propagating $\mathrm{Ca}^{2+}$ waves). In the presence of L-NAME, the smooth muscle cells depolarized and developed regular depolarizing oscillations, which were associated with increased tension and oscillations in tension; the peaks in $\mathrm{E}_{\mathrm{m}}$ immediately preceded peaks in tension. In the presence of L-NAME, oscillations in $\left[\mathrm{Ca}^{2+}\right]_{\mathrm{SMC}}$ were now synchronized and regular (synchronous $\mathrm{Ca}^{2+}$ oscillations) and were temporally linked to oscillations in tension. $\mathbf{c}$ The top coloured traces correspond to the average $\mathrm{F} / \mathrm{F}_{0}$ in 3 cells indicated by filled coloured squares on the images of the preparations, and the black traces are the average change in fluorescence from 10 equivalent regions in separate cells (see online version for colour). The lower coloured traces correspond to the percentage maximum change in fluorescence in single cells indicated by the open coloured squares (see online version for colour). Scale bar $=20 \mu \mathrm{m}$. Video files corresponding to the cropped regions (dashed lines) shown in control and L-NAME are available online (online supplementary videos). Summary data are shown in table 1. al $\left[\mathrm{Ca}^{2+}\right]_{\mathrm{SMC}}$ (data not shown) associated with the development of synchronous $\mathrm{Ca}^{2+}$ oscillations between smooth muscle cells that clearly linked temporally to changes in tension (fig. 1; online supplementary video 2; table 1).

The $\mathrm{BK}_{\mathrm{Ca}}$ channel inhibitor IbTx $(100 \mathrm{nM})$ and the sGC inhibitor ODQ $(10 \mu \mathrm{M})$ both mimicked this effect of LNAME. Each caused depolarization (to $\mathrm{E}_{\mathrm{m}}-40.3 \pm 1.8$ and $-35.5 \pm 6.0 \mathrm{mV}, \mathrm{n}=5$ and $\mathrm{n}=3$, respectively; fig. 2 ) and vasoconstriction (increases in tension of $3.7 \pm 0.8$ and $3.8 \pm 0.7 \mathrm{mN}, \mathrm{n}=6$ and $\mathrm{n}=3$, respectively; fig. 2 ) associated with the development of oscillations in $\mathrm{E}_{\mathrm{m}}$ temporally linked to oscillations in tone (table 1). Note that the vasomotion induced by ODQ was at a significantly lower frequency than that with either IbTx or LNAME (table 1).

Inhibition of RYRs with ryanodine $(10 \mu \mathrm{M})$ also mimicked the effect of L-NAME causing depolarization (13.5 $\pm 3.6 \mathrm{mV})$ and tension increases $(2.3 \pm 0.2 \mathrm{mN}, \mathrm{n}=5)$, and associated development of synchronous $\mathrm{E}_{\mathrm{m}}$ oscillations temporally linked with tension oscillations (fig. 3; table 1). Similarly, ryanodine stimulated synchronous $\mathrm{Ca}^{2+}$ oscillations in phase with tension changes (fig. 3; table 1).

\section{Effect of L-NAME and Ryanodine on Oscillations in \\ $\left[\mathrm{Ca}^{2+}\right]_{S M C}$ in the Presence of Nifedipine}

As ryanodine and L-NAME each evoke constrictor responses associated with depolarization (and consequent calcium entry via VGCC) the effects of these drugs were assessed in the presence of the L-type VGCC inhibitor, nifedipine $(1 \mu \mathrm{M})$. Under control conditions, nifedipine alone hyperpolarized $(6.4 \pm 2.4 \mathrm{mV})$ and relaxed $(0.76$ $\pm 0.03 \mathrm{mN})$ myogenic tone $(\mathrm{n}=4)$, associated with a slight but significant reduction in both the frequency $(0.20 \pm 0.02 \mathrm{~Hz}, \mathrm{n}=4, \mathrm{p}<0.01)$ and the number of cells 


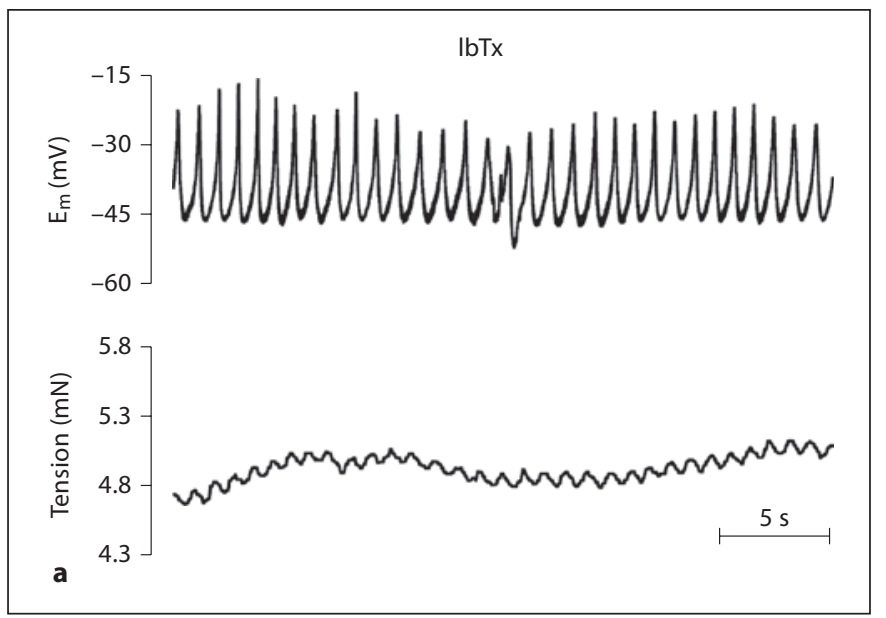

Fig. 2. Spontaneous activation of $\mathrm{BK}_{\mathrm{Ca}}$ channels and sGC prevent vasomotion. Original traces showing the effect of either the $\mathrm{BK}_{\mathrm{Ca}}$ channel inhibitor IbTx $(100 \mathrm{nM}, \mathbf{a})$ or the sGC inhibitor ODQ (10

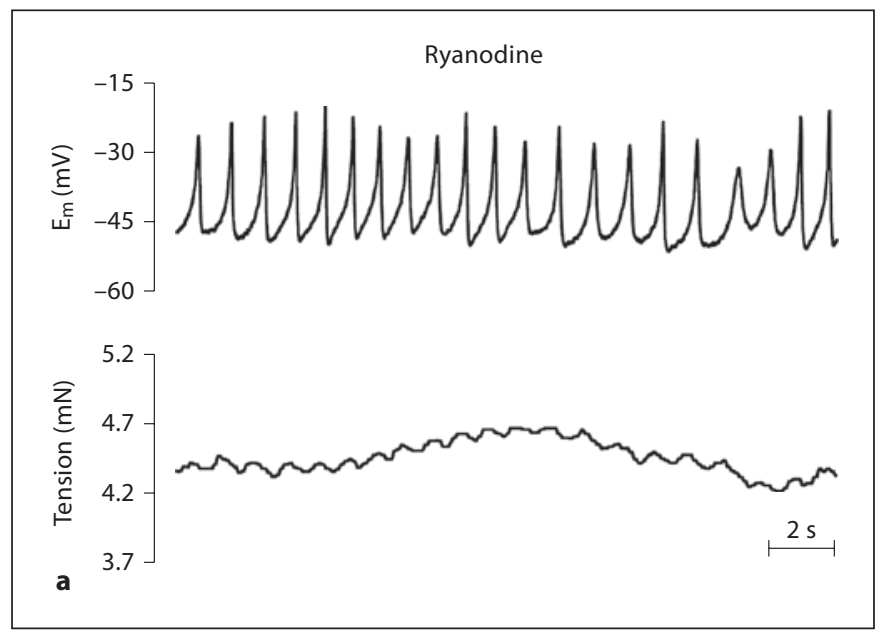

Fig. 3. Spontaneous activation of RYRs prevents vasomotion. Original traces of simultaneous recordings of membrane potential and tension (a) or simultaneous recordings of $\left[\mathrm{Ca}^{2+}\right]_{S M C}$ and tension (b). The traces show recordings obtained in the presence of the inhibitor of RYRs (ryanodine, $10 \mu \mathrm{M}$ ). Ryanodine caused depolarization and increased tension of the middle cerebral ar-

exhibiting asynchronous propagating $\mathrm{Ca}^{2+}$ waves (to $70 \%, 28$ of 40 cells; fig. 4). Subsequent addition of LNAME repolarized the smooth muscle $\mathrm{E}_{\mathrm{m}}$ (depolarization of $7.5 \pm 3.8 \mathrm{mV}, \mathrm{n}=4$ ) and caused a small increase in tension $(0.8 \pm 0.01 \mathrm{mN}, \mathrm{n}=4)$, returning $\mathrm{E}_{\mathrm{m}}$ and tension values close to values recorded in quiescent vessels.

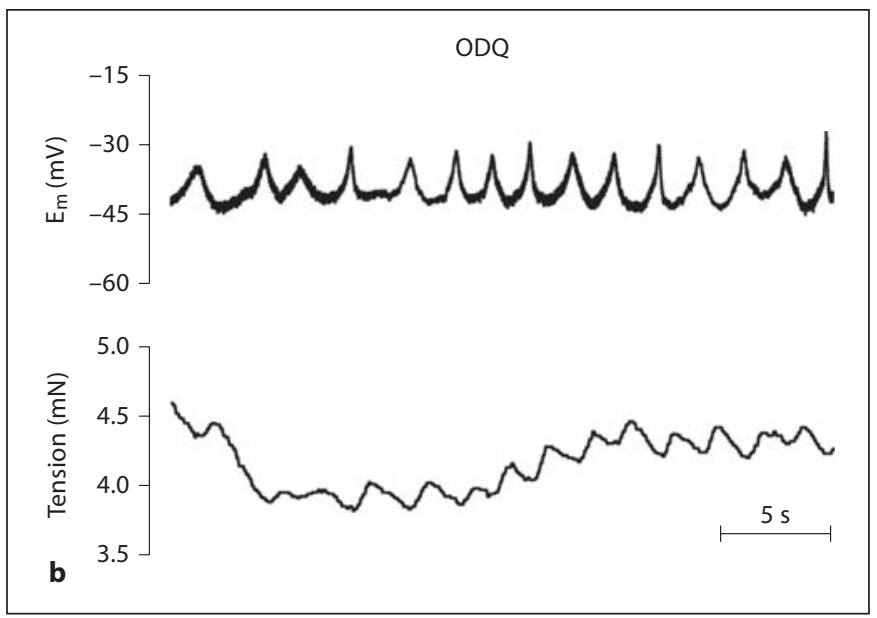

$\mu \mathrm{M}$; b) on simultaneous recordings of membrane potential $\left(\mathrm{E}_{\mathrm{m}}\right)$ and tension. Both IbTx and ODQ caused depolarization and increased tension and development of vasomotion.

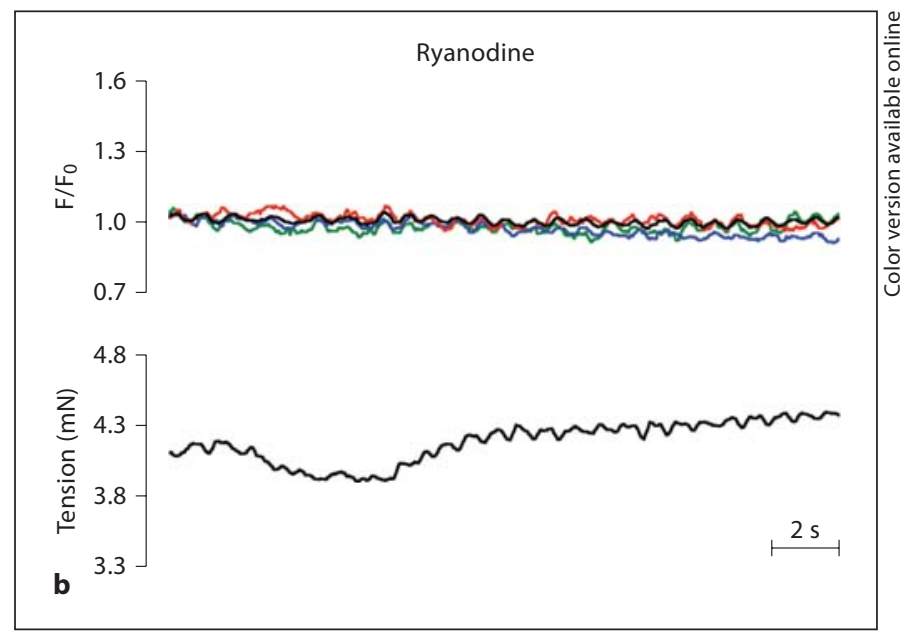

tery associated with development of depolarizing oscillations in $\mathrm{E}_{\mathrm{m}}$ that were temporally coupled to changes in tension. Ryanodine also caused development of synchronous $\mathrm{Ca}^{2+}$ oscillations that were temporally linked to oscillations in tension. $\left[\mathrm{Ca}^{2+}\right]_{\mathrm{SMC}}$ responses from 3 randomly selected cells are displayed (see online version for colour) as well as the 10 -cell average (black).

In the presence of nifedipine, L-NAME had no significant effect on the number of cells exhibiting asynchronous propagating $\mathrm{Ca}^{2+}$ waves $(68 \%, 27$ of 40 cells) or the wave frequency $(0.22 \pm 0.02 \mathrm{~Hz}, \mathrm{n}=4$; fig. 4$)$. In contrast, ryanodine completely abolished these $\mathrm{Ca}^{2+}$ waves (to 0 in 60 cells; fig. 4$)$. 


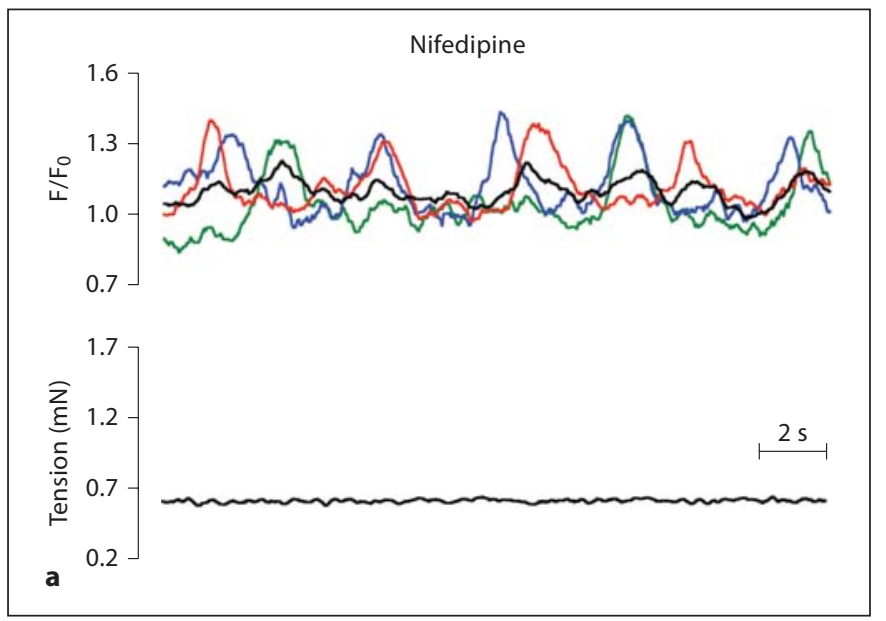

Fig. 4. Spontaneous NO release does not inhibit control, asynchronous propagating $\mathrm{Ca}^{2+}$ waves. Original traces showing the basal, asynchronous propagating $\mathrm{Ca}^{2+}$ waves from 3 representative cells (see online version for colour) and the 10-cell average (black; upper traces) and associated tension records (lower traces) in rat middle cerebral arteries in the presence of the L-type VGCC inhibitor nifedipine $(1 \mu \mathrm{M} ; \mathbf{a})$ and the combination of nifedipine and the NOS inhibitor L-NAME $(100 \mu \mathrm{M}$; b). Under control conditions, changes in $\left[\mathrm{Ca}^{2+}\right]_{S M C}$ were not synchronized between individual cells and were not coupled to changes in tension (as in fig. 1a). Nifedipine had no effect on the size of the asynchronous propagating $\mathrm{Ca}^{2+}$ waves. Subsequent addition of L-NAME also had no effect on these $\mathrm{Ca}^{2+}$ waves. c Average data showing the frequency of $\mathrm{Ca}^{2+}$ waves and the percentage of cells exhibiting this behaviour and the associated tension in control vessels and in the presence of nifedipine, nifedipine + L-NAME and nifedipine + ryanodine $(10 \mu \mathrm{M})$. Ryanodine completely abolished the $\mathrm{Ca}^{2+}$ waves in all cells of all vessels tested (60 cells). Data are expressed as means \pm SEM.

\section{Effect of Blocking VGCC and Application of}

Exogenous NO or Caffeine on L-NAME-Induced Tone

In vessels pre-constricted with L-NAME, nifedipine $(1 \mu \mathrm{M})$ abolished oscillations in $\mathrm{E}_{\mathrm{m}}$ and caused a repolarization (hyperpolarization of $11.7 \pm 1.9 \mathrm{mV}, \mathrm{n}=3$ ) to circa $-50 \mathrm{mV}$, the resting membrane potential in the absence of NOS inhibition. This was associated with complete reversal of L-NAME-induced tone $(93.1 \pm 1.6 \%$, $\mathrm{n}=3$ ). Furthermore, nifedipine caused a large decrease in $\left[\mathrm{Ca}^{2+}\right]_{S M C}$ (data not shown) and abolished the synchronous $\mathrm{Ca}^{2+}$ oscillations between SMC, unmasking the asynchronous propagating $\mathrm{Ca}^{2+}$ waves (compare fig. $4 \mathrm{~b}$ to fig. 1b).

In vessels pre-constricted with L-NAME, application of caffeine ( $30 \mu \mathrm{M}$ to $3 \mathrm{mM}$ ) induced concentration-dependent hyperpolarization $\left(\log \mathrm{EC}_{50}:-3.29 \pm 0.16, \mathrm{n}=\right.$ 4-9; $3 \mathrm{mM}$ : $18.9 \pm 5.5 \mathrm{mV}, \mathrm{n}=4)$ and relaxation $\left(\log \mathrm{EC}_{50}\right.$ :
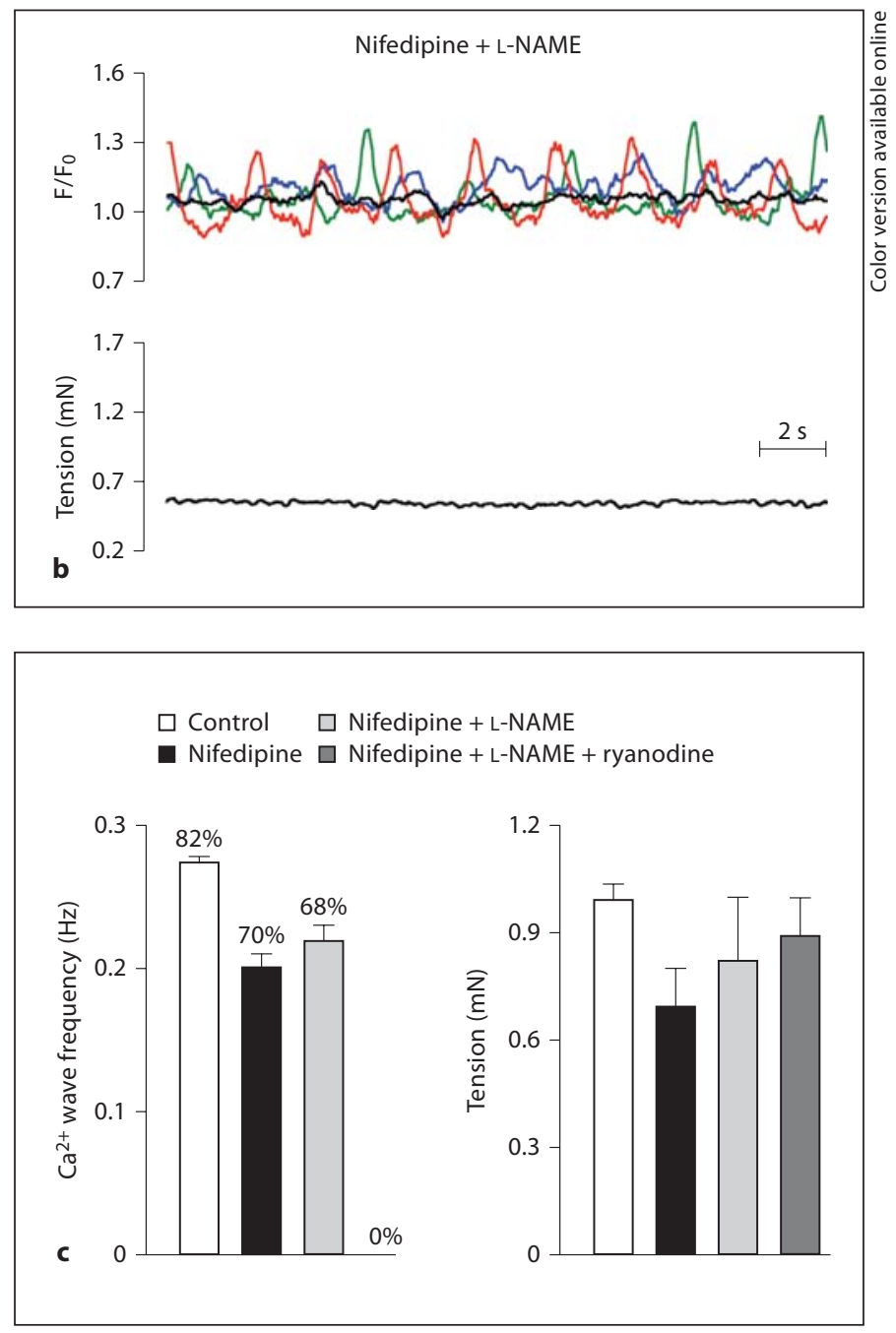

$-3.43 \pm 0.10, \mathrm{n}=7-8 ; 3 \mathrm{mM}: 91.8 \pm 4.2 \%$ relaxation, $\mathrm{n}=$ 8; fig. 5a). Hyperpolarization and relaxation to caffeine ( $1 \mathrm{mM}: 15.8 \pm 1.4 \mathrm{mV}, \mathrm{n}=9$ and $70.7 \pm 6.3 \%, \mathrm{n}=8$, respectively) were attenuated by IbTx (1 mM: $6.0 \pm 2.7 \mathrm{mV}$, $\mathrm{n}=4$ and $38.0 \pm 7.5 \%, \mathrm{n}=4$, respectively; fig. $5 \mathrm{a}$ ) and by ryanodine ( $1 \mathrm{mM}$ : $4.4 \pm 1.9 \mathrm{mV}$ and $40.0 \pm 30.9 \%$, respectively, $n=6)$.

Application of the NO donor NONOate ( $3 \mathrm{nM}$ to $1 \mu \mathrm{M}$ ) stimulated concentration-dependent hyperpolarization $\left(\log \mathrm{EC}_{50}:-7.05 \pm 0.18, \mathrm{n}=11-13 ; 1 \mu \mathrm{M}: 14.1 \pm 1.1 \mathrm{mV}\right.$, $\mathrm{n}=11)$ and relaxation $\left(\log \mathrm{EC}_{50}:-7.47 \pm 0.05, \mathrm{n}=13-14\right.$; $1 \mu \mathrm{M}$ : $89.0 \pm 1.8 \%$ relaxation, $\mathrm{n}=13$; fig. $5 \mathrm{~b}$ ). The $\mathrm{sGC}$ inhibitor ODQ $(1 \mu \mathrm{M})$ did not significantly affect hyperpolarization to NONOate $(\mathrm{n}=6-7 ; 1 \mu \mathrm{M}: 12.6 \pm 4.1 \mathrm{mV}$, $\mathrm{n}=6)$ but significantly attenuated the relaxation $(\mathrm{n}=6-7$; $1 \mu \mathrm{M}$ : $47.8 \pm 13.3 \%$ relaxation, $\mathrm{n}=7$; fig. $5 \mathrm{~b}$ ). Blockade of $\mathrm{BK}_{\mathrm{Ca}}$-channels with IbTx (100 nM) significantly inhibited 
Fig. 5. Caffeine and NONOate stimulate hyperpolarization and relaxation. Concentration response curves showing hyperpolarization (left panels) and relaxation (right panels) produced by caffeine (a) or the NO donor DEA-NONOate (b) in endothelium-intact (+EC) or endothelium-damaged arteries (-EC; c). Vessels were pre-incubated with L-NAME (100 $\mu \mathrm{M})$, IbTx (100 nM), ODQ (10 $\mu \mathrm{M})$ and/or ryanodine $(10 \mu \mathrm{M})$. Data are expressed as means $\pm \operatorname{SEM}(\mathrm{n}=4-9)$. ${ }^{*} \mathrm{p}<0.05$, significant difference from L-NAME (+EC) or control $(-\mathrm{EC}) ;{ }^{+} \mathrm{p}<0.05$, significant difference from baseline.
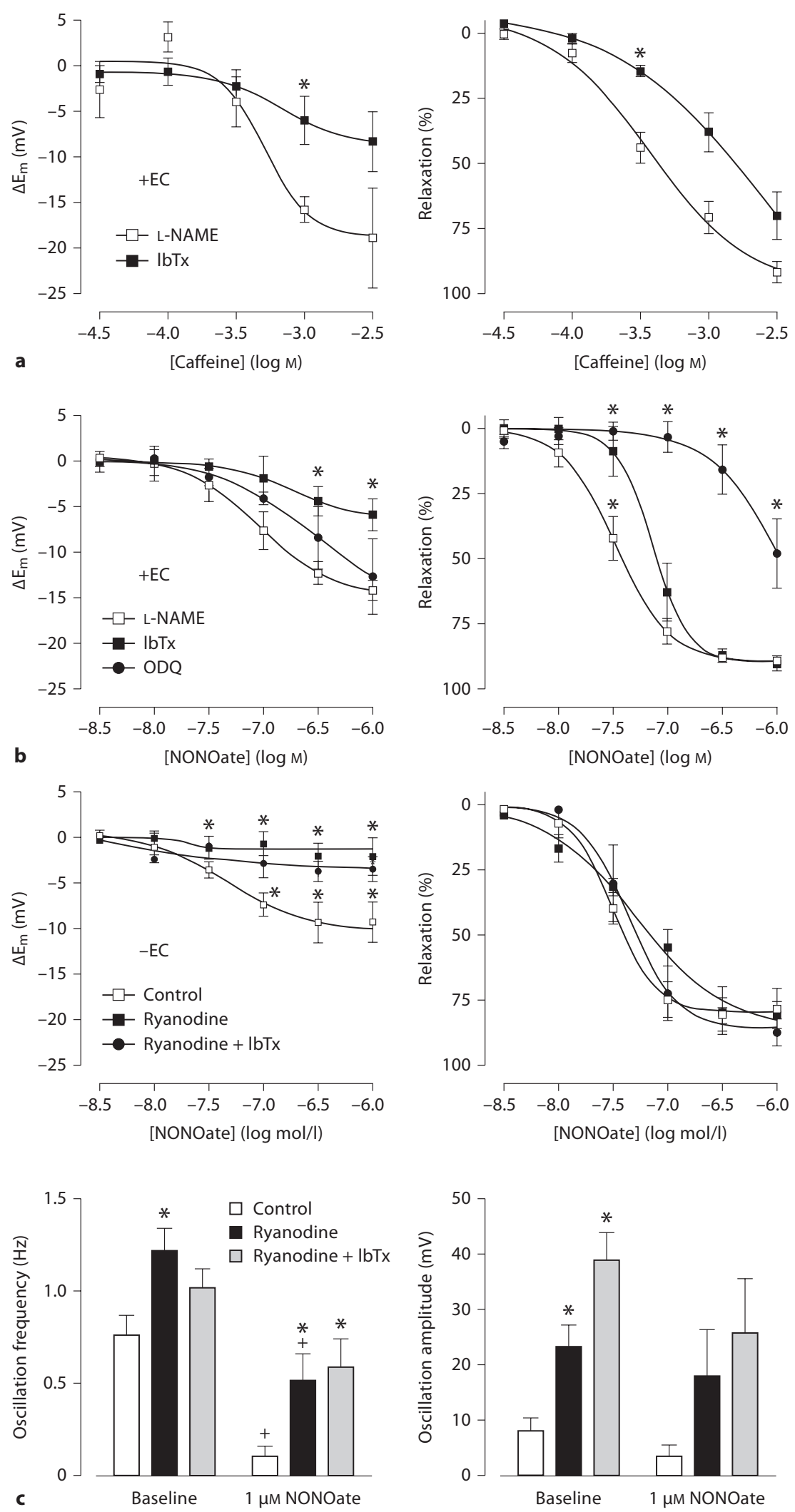
both NONOate-induced hyperpolarization and relaxation ( $\mathrm{n}=3-4$; fig. $5 \mathrm{~b})$.

\section{Effect of Removing the Endothelium on Myogenic}

Tone and the Response to Application of Exogenous

NO

Following removal of the endothelium, cerebral artery smooth muscle cells were depolarized $\left(\mathrm{E}_{\mathrm{m}}-45.9 \pm 2.2\right.$ $\mathrm{mV}, \mathrm{n}=12)$ and spontaneously developed tension (1.5 \pm $0.2 \mathrm{mN}, \mathrm{n}=12$ ) sometimes (9 of 12 records) associated with oscillations in both $\mathrm{E}_{\mathrm{m}}$ (amplitude: $4.5 \pm 1.2 \mathrm{mV}$; frequency: $0.84 \pm 0.20 \mathrm{~Hz}, \mathrm{n}=12$ ) and tension. In these denuded cerebral arteries, L-NAME did not further increase tension (data not shown).

The NO donor, NONOate ( $3 \mathrm{nM}$ to $1 \mu \mathrm{M}$ ) evoked concentration-dependent hyperpolarization and relaxation in denuded arteries $\left(\log \mathrm{EC}_{50}:-7.50 \pm 0.06 ; 1 \mu \mathrm{M}\right.$ : $9.2 \pm$ $2.2 \mathrm{mV}$ and $78.0 \pm 7.9 \%$ relaxation, $\mathrm{n}=6$; fig. $5 \mathrm{c}$ ). Ryanodine $(10 \mu \mathrm{M})$ caused a small increase in tone, which was associated with slight depolarization $\left(\mathrm{E}_{\mathrm{m}}-41.7 \pm 1.0 \mathrm{mV}\right.$, $\mathrm{n}=12$ ) and a significant increase in the amplitude of oscillations in $\mathrm{E}_{\mathrm{m}}(23.3 \pm 2.7 \mathrm{mV}$; frequency: $1.24 \pm 0.09$ $\mathrm{Hz}, \mathrm{n}=12$; fig. $5 \mathrm{c}$ ). These oscillations were not coupled to a detectable tension change. Ryanodine markedly reduced the hyperpolarization produced by NONOate, but did not significantly affect the relaxation. Interestingly, NONOate reduced the amplitude and frequency of ryanodine-mediated oscillations in $\mathrm{E}_{\mathrm{m}}(1 \mu \mathrm{M}$; fig. $5 \mathrm{c})$. The addition of IbTx did not modify the effects of ryanodine, apart from further increasing the amplitude of oscillations by around $10 \mathrm{mV}$ (amplitude significantly increased to $34.9 \pm 3.4 \mathrm{mV}$, frequency $1.29 \pm 0.09 \mathrm{~Hz}, \mathrm{n}=8$; fig. 5c).

To further characterize the action of NO, experiments were performed to assess an action at VGCC. In endothelium-denuded arteries, IbTx had no significant effect on hyperpolarization and relaxation responses to NONOate $(1 \mu \mathrm{M}$ : $7.4 \pm 3.1 \mathrm{mV}$ and $99.6 \pm 3.4 \%, \mathrm{n}=6$; compare fig. $5 \mathrm{c}$ to fig. $6 \mathrm{~b}$ ). However, in the additional presence of ODQ, the hyperpolarization and relaxation to NONOate were reduced (fig. 6a, b). Subsequent addition of the Ltype VGCC opener BayK 8644 did not significantly alter membrane potential (hyperpolarization of $3.7 \pm 3.8 \mathrm{mV}$ ) but contracted arteries $(1.2 \pm 0.2 \mathrm{mN}, \mathrm{n}=5)$, and significantly increased both the frequency and amplitude of oscillations in $E_{m}$ (fig. 6c). In the presence of this combination of inhibitors, the hyperpolarization to NONOate was effectively abolished, and the relaxation to NONOate markedly reduced.

sGC-Independent Effects of $\mathrm{NO}$ on

Cerebral Vasomotion

\section{Direct Action of NO on VGCC}

The average resting $\mathrm{E}_{\mathrm{m}}$ of isolated smooth muscle cells was $-51.1 \pm 2.0 \mathrm{mV}(\mathrm{n}=12)$. In these unstretched and unstimulated cells, $\mathrm{E}_{\mathrm{m}}$ tended to oscillate (amplitude of $15.4 \pm 2.8 \mathrm{mV}, \mathrm{n}=12$ ), but a clear pattern was not observed (fig. 7a). In contrast, under similar conditions at $37^{\circ} \mathrm{C}$, the resting $\mathrm{E}_{\mathrm{m}}$ of smooth muscle cells isolated from mesenteric arteries tended to remain stable at $-54.5 \pm$ $0.6 \mathrm{mV}$ (with less frequent and lower amplitude oscillations of $5.2 \pm 0.5 \mathrm{mV}, \mathrm{n}=11$ ). Addition of $1 \mu \mathrm{M}$ NONOate to the superfusion solution stimulated hyperpolarization and abolished the oscillations in $\mathrm{E}_{\mathrm{m}}$ (fig. 7a). In whole cell mode, steady-state $\mathrm{I}_{\mathrm{CaL}}$ was recorded for $1 \mathrm{~min}$ using the ramp protocol. Application of NONOate $(1 \mu \mathrm{M})$ to the bath induced a significant reduction in $\mathrm{I}_{\mathrm{CaL}}$ that was not inhibited by ODQ (fig. 7c, d; $n=6-7$ ). The effect of NONOate on $\mathrm{I}_{\mathrm{CaL}}$ was time dependent (fig. $7 \mathrm{~d}$ ), so values were taken at $10 \mathrm{~min}$ following application of NONOate.

\section{Discussion}

These data from the rat middle cerebral artery indicate that myogenic tone and vasomotion are normally suppressed by basal release of endothelium-derived NO that inhibits VGCC largely via sGC-independent pathways. This can occur either through an effect at RYR and activation of smooth muscle cell $\mathrm{BK}_{\mathrm{Ca}}$ channels, or a direct action independent of voltage. The activation of $\mathrm{BK}_{\mathrm{Ca}}$ channels appears to involve in part an indirect action of NO due to stimulation of $\mathrm{Ca}^{2+}$ release from ryanodinesensitive $\mathrm{Ca}^{2+}$ stores, but also in part a direct action of $\mathrm{NO}$ on the $\mathrm{K}_{\mathrm{Ca}}$ channel. Therefore, upon inhibition of NOS, smooth muscle cell depolarization due to closure of $\mathrm{BK}_{\mathrm{Ca}}$ channels and the removal of an inhibitory influence, both lead to opening of VGCCs which is followed by a rise in $\left[\mathrm{Ca}^{2+}\right]_{\mathrm{SMC}}$ and tension leading to arterial vasomotion.

The finding that myogenic tone is normally suppressed by basal release of NO in rat middle cerebral arteries is consistent with previous studies using cerebral arteries [14-19] and a variety of other vessels that exhibit myogenic tone including small coronary arteries $[11,12]$. By suppressing myogenic tone, $\mathrm{NO}$ also suppresses vasomotion in the middle cerebral artery. Nifedipine fully reversed the effects of L-NAME, reversing tension and abolishing synchronized oscillations in both $\mathrm{E}_{\mathrm{m}}$ and $\left[\mathrm{Ca}^{2+}\right]_{\text {SMC }}$. Therefore, it is apparent that opening VGCCs is essential for vasomotion to develop, consistent with many other vessels $[1,36]$. Despite this, we cannot rule 


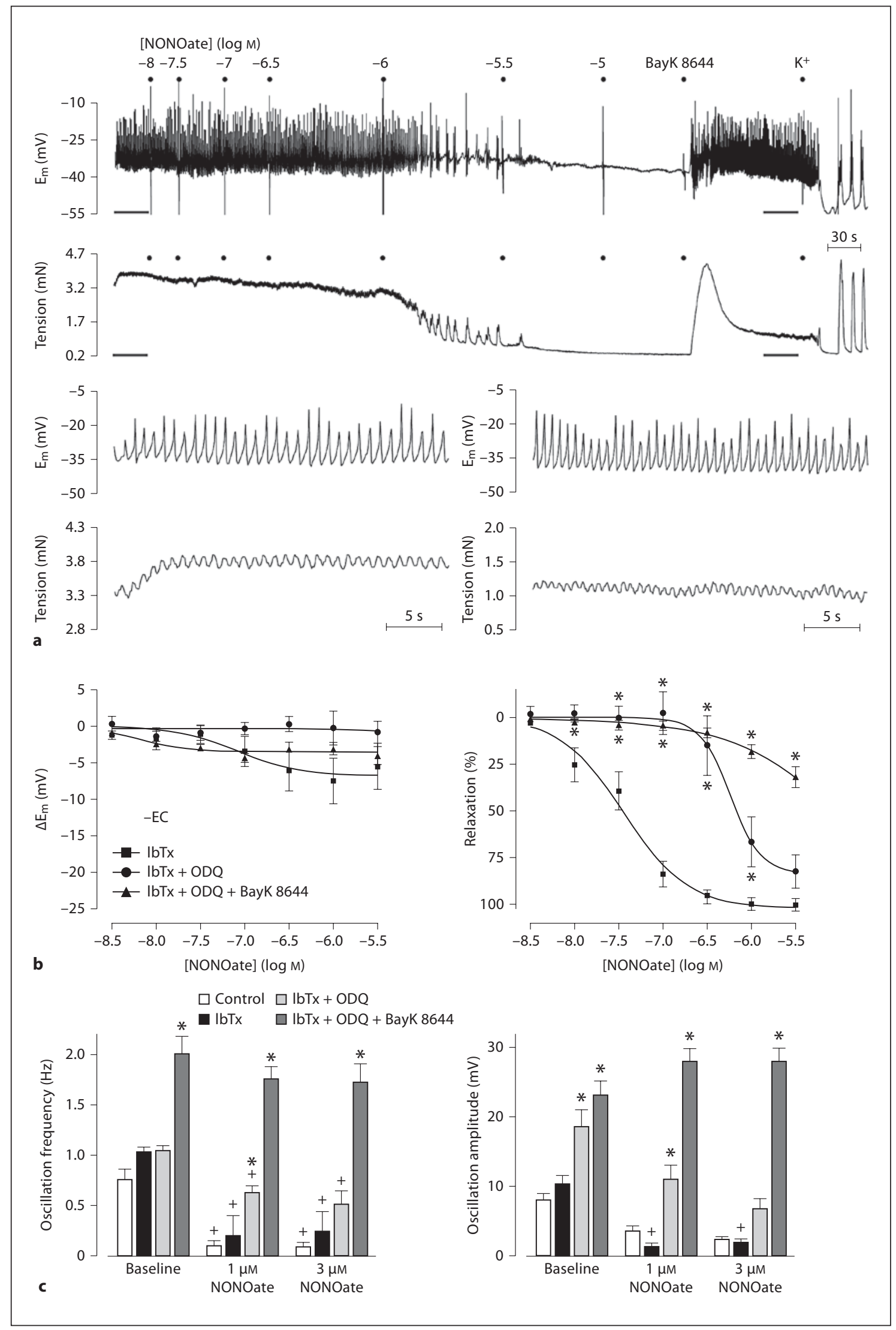


out the involvement of other ion channels. Once the intracellular $\mathrm{Ca}^{2+}$ levels rise and the membrane depolarizes, other channels would be stimulated to open, including voltage-gated $\mathrm{Na}^{+}$channels, $\mathrm{Ca}^{2+}$-activated $\mathrm{Cl}^{-}$channels and $\mathrm{K}_{\mathrm{Ca}}$ channels. Furthermore, as both the endothelial and smooth muscle cells are coupled by homocellular and heterocellular gap junctions in this artery [37], it remains possible that the endothelium influences membrane potential through NO or other mediators. For example, changes in endothelial cell $\mathrm{Ca}^{2+}$ are responsible for the release of $\mathrm{NO}$, so endothelial cell $\mathrm{K}_{\mathrm{Ca}}$ channels may also play a role in the observed changes in membrane potential.

While basal release of NO is known to suppress myogenic tone (and vasomotion), the precise mechanisms are unclear. However, it is likely that NO acts via multiple mechanisms, a few of which are shown in figure 8. NO can suppress the contractile apparatus of the smooth muscle cells via the cGMP pathway. Indeed, ODQ produced increases in tension and depolarization (similar to L-NAME, albeit with a lower frequency of vasomotion), suggesting that $\mathrm{sGC}$ somehow stimulates hyperpolarization, perhaps via an action at $\mathrm{BK}_{\mathrm{Ca}}$ channels through PKG-dependent mechanisms $[24,25]$ or by an action on RYRs $[27,28]$. In addition, our data are consistent with a cGMP-independent action of $\mathrm{NO}$ at $\mathrm{BK}_{\mathrm{Ca}}$ channels, because in the presence of ODQ the $\mathrm{BK}_{\mathrm{Ca}}$ channel-mediated hyperpolarization induced by the NO donor was reduced, but not significantly, leaving an ODQ-insensitive hyper-

Fig. 6. Application of exogenous NO (NONOate $3 \mathrm{nM}$ to $3 \mu \mathrm{M}$ ) appears to directly inactivate VGCCs in endothelium-denuded middle cerebral arteries. a Original trace showing that in the combined inhibition of $\mathrm{BK}_{\mathrm{Ca}}$ channels (IbTx, $100 \mathrm{nM}$ ) and sGC $(\mathrm{ODQ}, 10 \mu \mathrm{M})$, NONOate induces a reduction in membrane potential oscillation frequency and amplitude (upper trace) that is associated with relaxation (lower trace). The effects of NONOate were fully reversed by an opener of L-type VGCCs (BayK 8644, $1 \mu \mathrm{M})$. Highlighted regions (gray lines) are reproduced in an extended time base to demonstrate that BayK 8644 fully reverses the effects of NONOate. Also shown are concentration response curves (b) showing the effect of NONOate on membrane potential and tension as well as histograms (c) showing the effect of NONOate on oscillation frequency and amplitude in the presence of IbTx, the combined presence of IbTx and ODQ and in the additional presence of BayK 8644. Note that following inhibition of $\mathrm{BK}_{\mathrm{Ca}}$ and sGC, NONOate-mediated relaxation does not seem to involve a true hyperpolarization but results from a reduction in both frequency and amplitude of the oscillations in membrane potential. Data are expressed as means \pm SEM. ${ }^{*} \mathrm{p}<0.05$, significant difference from control; ${ }^{+} \mathrm{p}<0.05$, significant difference from baseline.

sGC-Independent Effects of NO on Cerebral Vasomotion polarization. This suggests that endogenous $\mathrm{NO}$ activates $\mathrm{BK}_{\mathrm{Ca}}$ channels either directly $[21,22]$ or via stimulation of $\mathrm{Ca}^{2+}$ release (for example sparks) from ryanodine-sensitive stores (by opening RYRs). Evidence for the latter comes from the ability of ryanodine to block NONOateinduced hyperpolarization in endothelium-damaged vessels. Despite this block, NONOate was still able to reduce the frequency and amplitude of the depolarizing spikes (oscillations in $\mathrm{E}_{\mathrm{m}}$ ) linked with the vasomotion generated by ryanodine. This suggests that $\mathrm{NO}$ acts to prevent the opening of the ion channel responsible for the depolarization. Further evidence consistent with a cGMPindependent action of NO on RYRs was the ability of ryanodine to (1) stimulate vasomotion, mimicking the effect of NOS inhibition, and (2) inhibit the IbTx-sensitive hyperpolarization to caffeine.

Although it is likely that a major component of NOinduced suppression of myogenic tone involves a stimulation of $\mathrm{Ca}^{2+}$ release events, our data argue against an essential role for NO in the activation of RYRs. In the presence of nifedipine, L-NAME did not markedly prevent the basal asynchronous propagating $\mathrm{Ca}^{2+}$ waves, whereas ryanodine did. This is in contrast to previous observations in cerebral arteries by Mandala et al. [26], who suggested that NO was absolutely essential for RYR activation (and thus for activation of $\mathrm{BK}_{\mathrm{Ca}}$ channels) because spontaneous $\mathrm{Ca}^{2+}$ sparks were reduced by around $50 \%$ with NOS inhibitors or endothelium removal. However, following on from our observations, it is likely that asynchronous propagating $\mathrm{Ca}^{2+}$ waves were masked by the $\mathrm{Ca}^{2+}$ influx through the L-type VGCCs and development of synchronous $\mathrm{Ca}^{2+}$ oscillations, as observed in the present study. Therefore, while the activation of $\mathrm{BK}_{\mathrm{Ca}}$ channels by NO likely involves direct stimulation of RYR-controlled $\mathrm{Ca}^{2+}$ stores, this action of NO is not an essential step in the activation of RYR. It follows that as RYR stimulation is not necessarily associated with $\mathrm{NO}$, an as yet unidentified process may also modulate vasomotion. In support of this conclusion, inhibition of RYR in the absence of a functional endothelium (and therefore NO synthesis) resulted in a small increase in tension as well as development of large, regular depolarizing oscillations in $\mathrm{E}_{\mathrm{m}}$.

Further experiments in the absence of functional endothelium showed that NONOate appears to directly inhibit VGCCs. In the presence of both IbTx and ODQ, NONOate responses mimicked those of nifedipine under control conditions and in the presence of L-NAME, that is, complete block of the oscillations in $\mathrm{E}_{\mathrm{m}}$ associated with a small hyperpolarization, and relaxation. This di- 


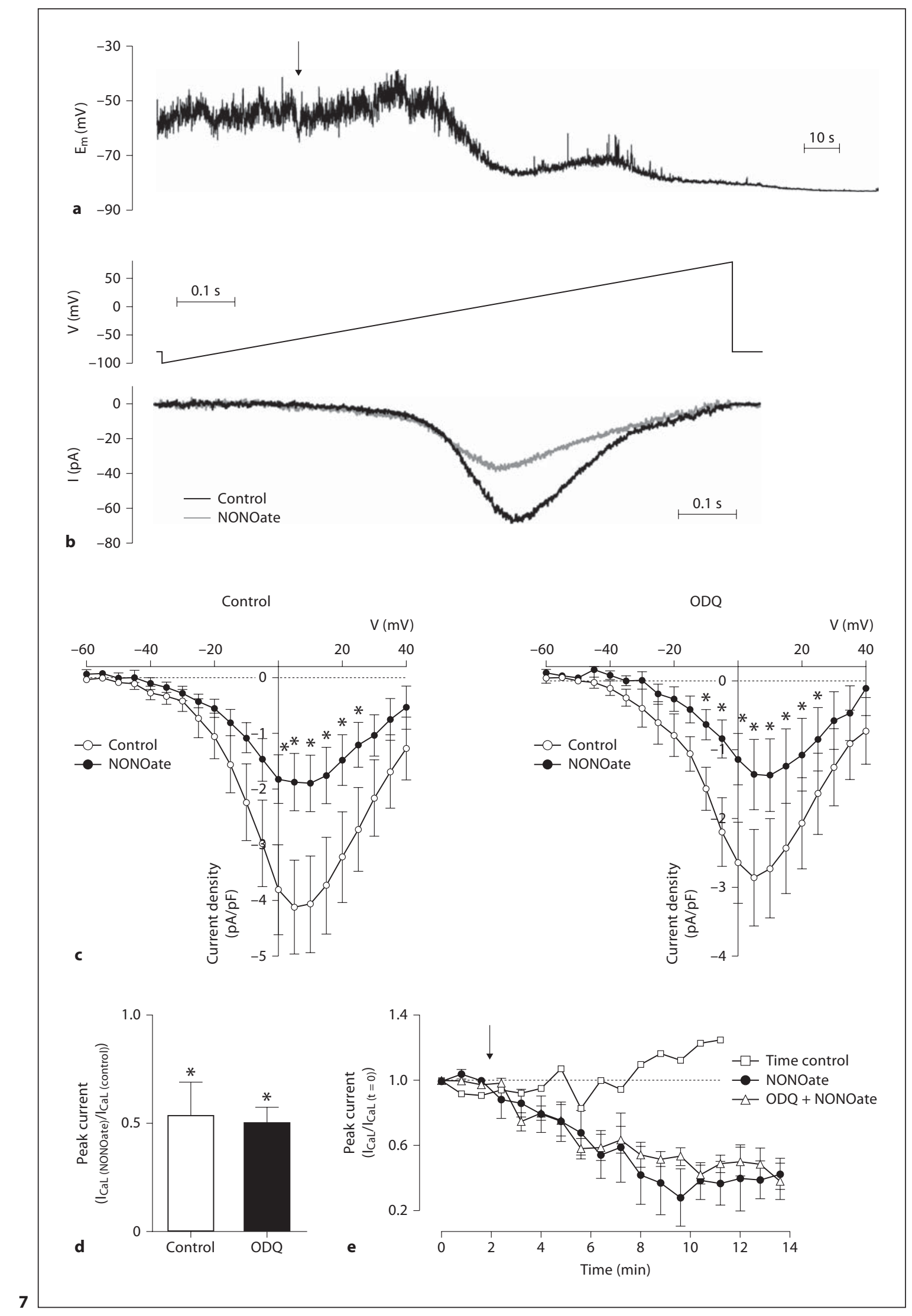


Fig. 8. Schematic depicting actions of NO in cerebral artery smooth muscle cells. Release of NO from endothelial cells can suppress vasomotion via multiple mechanisms. (i) Stimulation of sGC can relax smooth muscle cells via voltage-independent pathways. (ii) NO can directly activate $\mathrm{BK}_{\mathrm{Ca}}$ channels, leading to hyperpolarization, closure of VGCC and relaxation. (iii) The action of $\mathrm{NO}$ on $\mathrm{BK}_{\mathrm{Ca}}$ channel activity can be indirect, via a direct action of $\mathrm{NO}$ at RYRs, or (iv) via an intermediate (such as sGC/PKG). RyRs are also activated by NO-independent mechanisms (v) including those related to store filling via the $\mathrm{Ca}^{2+}$ ATPase (SERCA). This depiction is based on the close association of RyRs to $\mathrm{BK}_{\mathrm{Ca}}$-channels, which are spatially separated from the $\mathrm{Ca}^{2+}$ release and influx mechanisms associated with contraction $[43,44]$.

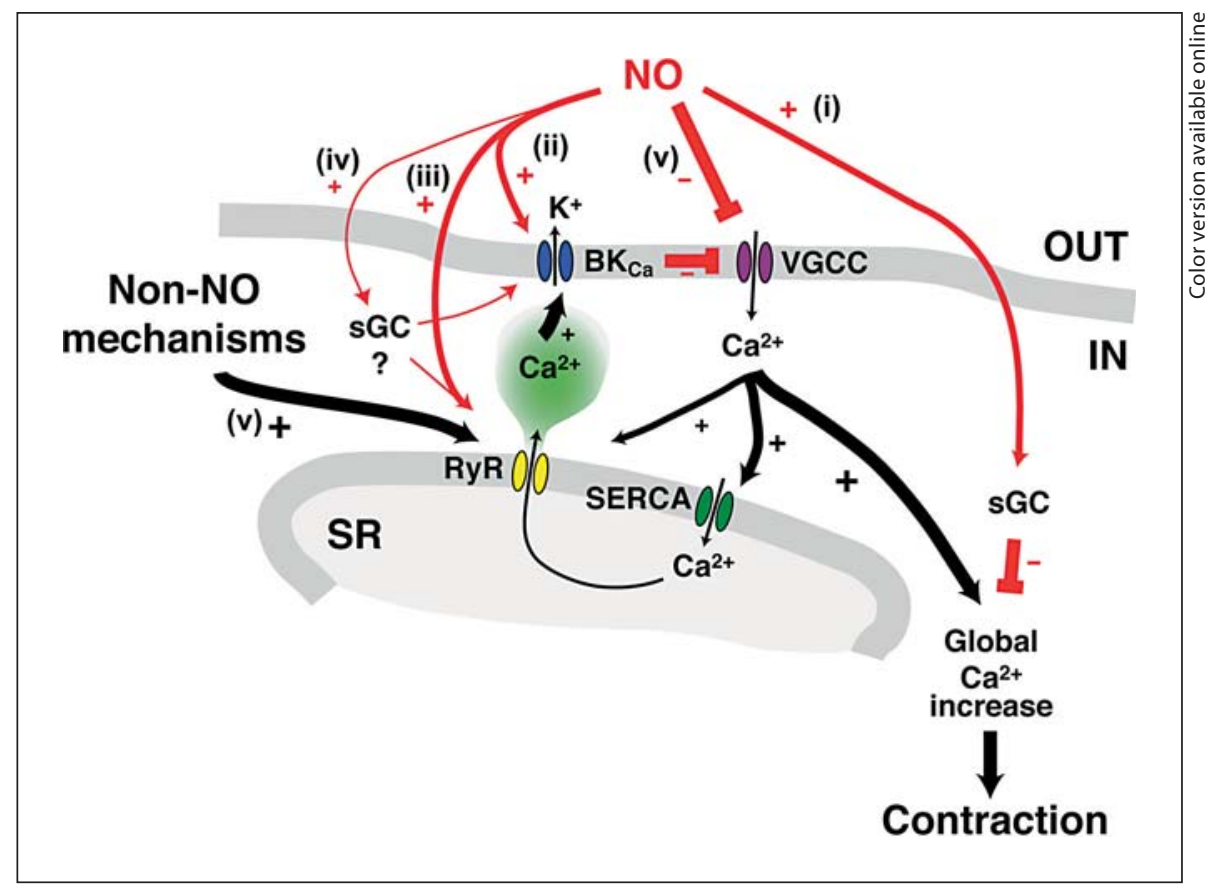

rect effect of NONOate on VGCC was confirmed in isolated smooth muscle cells, where $\mathrm{I}_{\mathrm{CaL}}$ was markedly reduced. The effect of NONOate on $\mathrm{I}_{\mathrm{CaL}}$ in the isolated cells appears to be, at least in part, via a direct action on the channel protein or associated proteins, rather than via a cGMP-dependent mechanism. This is consistent with previous findings in the carotid body, where Summers et al. [33] showed that NO-mediated inhibition of $\mathrm{I}_{\mathrm{CaL}}$ occurs via S-nitrosylation of the channel protein, and that $\mathrm{S}$-alkylation of the free cysteine residues by NEM pre-

Fig. 7. NONOate inhibits VGCC via a sGC-independent mechanism. a In isolated smooth muscle cells at $37^{\circ} \mathrm{C}$ under currentclamp conditions the resting $\mathrm{E}_{\mathrm{m}}$ oscillated. Addition of $1 \mu \mathrm{M}$ NONOate (indicated by arrow) hyperpolarized the cell and abolished the oscillations in $\mathrm{E}_{\mathrm{m}}$. $\mathbf{b}$ The voltage protocol for detecting $\mathrm{I}_{\mathrm{CaL}}$ (top) resulted in inward current that was reduced by $1 \mu \mathrm{M}$ NONOate (bottom). c Mean current voltage relationships under both control conditions $(n=6$, left) and after pretreatment with ODQ ( $n=7$, right) show that the inhibition of $\mathrm{I}_{\mathrm{CaL}}$ by $1 \mu \mathrm{M}$ NONOate was not sensitive to ODQ. d The peak current was reduced by approximately $50 \%$ under both conditions. Data are expressed as means \pm SEM. ${ }^{*} \mathrm{p}<0.05$, significant difference from control. e Effect of $1 \mu \mathrm{M}$ NONOate (added at arrow) on peak $\mathrm{I}_{\mathrm{CaL}}$ amplitude over time, for data shown in $\mathbf{c}$ and $\mathbf{d}$. NONOate-induced $\mathrm{I}_{\mathrm{CaL}}$ inhibition took minutes to occur, and was not due to current rundown (time control).

sGC-Independent Effects of NO on Cerebral Vasomotion vented the modulation by the NO donor sodium nitroprusside, rather than via the activation of sGC.

Further evidence for the action of $\mathrm{NO}$ on $\mathrm{I}_{\mathrm{CaL}}$ in our studies to be induced by nitrosylation rather than via the cGMP/PKG pathway may come from the time course of NONOate-induced inhibition, which took minutes to tens of minutes to occur. Previous studies of neuronal $\mathrm{BK}_{\mathrm{Ca}}$ channels suggest that not only does nitrosylation require a higher concentration of NO than the PKG pathway, but it develops with a much slower time course [38, 39].

The action of NO at VGCC was fully reversed by adding the direct opener of L-type VGCC, suggesting that the sites of action are independent. Although there is evidence that both NO and BayK 8644 each evoke their effects on the L-type VGCC via the pore-forming $\alpha_{1 c}$-subunit, BayK 8644, which competitively competes with nifedipine, binds from the extracellular surface to access the dihydopyridine receptor site within the channel [40, 41]. The site of NO-induced VGCC modulation by nitrosylation still remains to be elucidated, although there is evidence that VGCC function can be impaired by nitrosylation of an intracellular tyrosine residue (Y2134) situated in the src kinase protein-binding domain of the carboxy terminal of the $\alpha_{1 c}$-subunit [42].

In summary, in rat middle cerebral arteries a basal release of NO from the endothelium suppresses myogenic

J Vasc Res 2010;47:93-107 
tone. This suppression of myogenic tone is due, at least in part, to the ability of $\mathrm{NO}$ to stimulate $\mathrm{BK}_{\mathrm{Ca}}$ channels by activating ryanodine-sensitive $\mathrm{Ca}^{2+}$ stores. Following inhibition of NOS, the $\mathrm{BK}_{\mathrm{Ca}}$ channels close, leading to depolarization, with an associated increase in tension and the development of vasomotion. Therefore, our data indicate that basal NO release represents an important controlling mechanism on myogenic tone in cerebral arteries. In disease states where NO synthesis is compromised, disruption of this constitutive suppression of myogenic tone would be predicted to increase significantly the risk of brain ischaemia.

\section{Acknowledgments}

This work was supported by the British Heart Foundation (PG/04/069) and the Wellcome Trust (079677 and 07543/04).

\section{References}

1 Davis MJ, Hill MA: Signaling mechanisms underlying the vascular myogenic response. Physiol Rev 1999;79:387-423.

-2 Fujii K, Heistad DD, Faraci FM: Ionic mechanisms in spontaneous vasomotion of the rat basilar artery in vivo. J Physiol 1990;430: 389-398.

- 3 Hill MA, Zou H, Potocnik SJ, Meininger GA, Davis MJ: Invited review: arteriolar smooth muscle mechanotransduction: $\mathrm{Ca}^{2+}$ signaling pathways underlying myogenic reactivity. J Appl Physiol 2001;91:973-983.

-4 Diehl RR, Diehl B, Sitzer M, Hennerici M: Spontaneous oscillations in cerebral blood flow velocity in normal humans and in patients with carotid artery disease. Neurosci Lett 1991;127:5-8.

5 Dirnagl U, Lindauer U, Villringer A: Nitric oxide synthase blockade enhances vasomotion in the cerebral microcirculation of anesthetized rats. Microvasc Res 1993;45:318323.

-6 Peng H, Matchkov V, Ivarsen A, Aalkjaer C, Nilsson $\mathrm{H}$ : Hypothesis for the initiation of vasomotion. Circ Res 2001;88:810-815.

7 Haddock RE, Hill CE: Differential activation of ion channels by inositol 1,4,5-trisphosphate $\left(\mathrm{IP}_{3}\right)$ - and ryanodine-sensitive calcium stores in rat basilar artery vasomotion. J Physiol 2002;545:615-627.

-8 Biswal BB, Hudetz AG: Synchronous oscillations in cerebrocortical capillary red blood cell velocity after nitric oxide synthase inhibition. Microvasc Res 1996;52:1-12.

-9 Jung CS, Oldfield EH, Harvey-White J, Espey MG, Zimmermann M, Seifert V, Pluta RM: Association of an endogenous inhibitor of nitric oxide synthase with cerebral vasospasm in patients with aneurysmal subarachnoid hemorrhage. J Neurosurg 2007; 107:945-950.

10 Pluta RM: Delayed cerebral vasospasm and nitric oxide: review, new hypothesis, and proposed treatment. Pharmacol Ther 2005; 105:23-56.

-11 Garcia SR, Bund SJ: Nitric oxide modulation of coronary artery myogenic tone in spontaneously hypertensive and Wistar-Kyoto rats. Clin Sci (Lond) 1998;94:225-229.
12 Graves JE, Greenwood IA, Large WA: Tonic regulation of vascular tone by nitric oxide and chloride ions in rat isolated small coronary arteries. Am J Physiol Heart Circ Physiol 2000;279:H2604-H2611.

13 Marrelli SP, Eckmann MS, Hunte MS: Role of endothelial intermediate conductance $\mathrm{K}_{\mathrm{Ca}}$ channels in cerebral EDHF-mediated dilations. Am J Physiol Heart Circ Physiol 2003 285:H1590-H1599.

14 Golding EM, Steenberg ML, Johnson TD, Bryan RM: Nitric oxide in the potassium-induced response of the rat middle cerebral artery: a possible permissive role. Brain Res 2001;889:98-104.

-15 Peng HL, Jensen PE, Nilsson H, Aalkjar C: Effect of acidosis on tension and $\left[\mathrm{Ca}^{2+}\right]_{\mathrm{i}}$ in rat cerebral arteries: is there a role for membrane potential? Am J Physiol Heart Circ Physiol 1998;274:H655-H662.

-16 Zimmermann PA, Knot HJ, Stevenson AS, Nelson MT: Increased myogenic tone and diminished responsiveness to ATP-sensitive $\mathrm{K}^{+}$channel openers in cerebral arteries from diabetic rats. Circ Res 1997;81:996-1004.

17 Knot HJ, Zimmermann PA, Nelson MT: Extracellular $\mathrm{K}^{+}$-induced hyperpolarizations and dilatations of rat coronary and cerebral arteries involve inward rectifier $\mathrm{K}^{+}$channels. J Physiol 1996;492:419-430.

18 McNeish AJ, Dora KA, Garland CJ: Possible role for $\mathrm{K}^{+}$in endothelium-derived hyperpolarizing factor-linked dilatation in rat middle cerebral artery. Stroke 2005;36:15261532 .

19 Geary GG, Krause DN, Duckles SP: Estrogen reduces myogenic tone through a nitric oxide-dependent mechanism in rat cerebral arteries. Am J Physiol Heart Circ Physiol 1998; 275:H292-H300.

20 Sakagami K, Kawamura H, Wu DM, Puro DG: Nitric oxide/cGMP-induced inhibition of calcium and chloride currents in retinal pericytes. Microvasc Res 2001;62:196-203.

-21 Bolotina VM, Najibi S, Palacino JJ, Pagano PJ, Cohen RA: Nitric oxide directly activates calcium-dependent potassium channels in vascular smooth muscle. Nature 1994;368: 850-853.
22 Mistry DK, Garland CJ: Nitric oxide (NO)induced activation of large conductance $\mathrm{Ca}^{2+}$-dependent $\mathrm{K}^{+}$channels $\left(\mathrm{BK}_{\mathrm{Ca}}\right)$ in smooth muscle cells isolated from the rat mesenteric artery. Br J Pharmacol 1998;124: 1131-1140.

23 Homer KL, Wanstall JC: Cyclic GMP-independent relaxation of rat pulmonary artery by spermine NONOate, a diazeniumdiolate nitric oxide donor. Br J Pharmacol 2000;131: 673-682.

24 Robertson BE, Schubert R, Hescheler J, Nelson MT: cGMP-dependent protein kinase activates $\mathrm{Ca}$-activated $\mathrm{K}$ channels in cerebral artery smooth muscle cells. Am J Physiol Cell Physiol 1993;265:C299-C303.

-25 Archer SL, Huang JMC, Hampl V, Nelson DP, Shultz PJ, Weir EK: Nitric oxide and cGMP cause vasorelaxation by activation of a charybdotoxin-sensitive $\mathrm{K}$ channel by cGMP-dependent protein kinase. Proc Natl Acad Sci USA 1994;91:7583-7587.

26 Mandala M, Heppner TJ, Bonev AD, Nelson MT: Effect of endogenous and exogenous nitric oxide on calcium sparks as targets for vasodilation in rat cerebral artery. Nitric Oxide 2007;16:104-109.

27 Eu JP, Xu L, Stamler JS, Meissner G: Regulation of ryanodine receptors by reactive nitrogen species. Biochem Pharmacol 1999;57: 1079-1084.

28 Suko J, Maurer-Fogy I, Plank B, Bertel O, Wyskovsky W, Hohenegger M, Hellmann G: Phosphorylation of serine 2843 in ryanodine receptor-calcium release channel of skeletal muscle by cAMP-, cGMP- and CaM-dependent protein kinase. Biochim Biophys Acta 1993;1175:193-206.

29 Gerzanich V, Zhang F, West GA, Simard JM: Chronic nicotine alters NO signaling of $\mathrm{Ca}^{2+}$ channels in cerebral arterioles. Circ Res 2001;88:359-365.

30 Quignard JF, Frapier JM, Harricane MC, Albat B, Nargeot J, Richard S: Voltage-gated calcium channel currents in human coronary myocytes. Regulation by cyclic GMP and nitric oxide. J Clin Invest 1997;99:185193. 
-31 Tewari K, Simard JM: Sodium nitroprusside and cGMP decrease $\mathrm{Ca}^{2+}$ channel availability in basilar artery smooth muscle cells. Pflugers Arch 1997;433:304-311.

-32 Almanza A, Navarrete F, Vega R, Soto E: Modulation of voltage-gated $\mathrm{Ca}^{2+}$ current in vestibular hair cells by nitric oxide. J Neurophysiol 2007;97:1188-1195.

33 Summers BA, Overholt JL, Prabhakar NR: Nitric oxide inhibits L-type $\mathrm{Ca}^{2+}$ current in glomus cells of the rabbit carotid body via a cGMP-independent mechanism. Journal of neurophysiology 1999;81:1449-1457.

-34 Jian K, Chen M, Cao X, Zhu XH, Fung ML, Gao TM: Nitric oxide modulation of voltagegated calcium current by S-nitrosylation and cGMP pathway in cultured rat hippocampal neurons. Biochem Biophys Res Commun 2007;359:481-485.
35 Garland CJ, McPherson GA: Evidence that nitric oxide does not mediate the hyperpolarization and relaxation to acetylcholine in the rat small mesenteric artery. Br J Pharmacol 1992;105:429-435.

36 Haddock RE, Hill CE: Rhythmicity in arterial smooth muscle. J Physiol 2005;566:645656.

37 McNeish AJ, Sandow SL, Neylon CB, Chen MX, Dora KA, Garland CJ: Evidence for involvement of both $\mathrm{IK}_{\mathrm{Ca}}$ and $\mathrm{SK}_{\mathrm{Ca}}$ channels in hyperpolarizing responses of the rat middle cerebral artery. Stroke 2006;37:1277-1282.

38 Ahern GP, Klyachko VA, Jackson MB: cGMP and S-nitrosylation: two routes for modulation of neuronal excitability by NO. Trends Neurosci 2002;25:510-517.

39 Klyachko VA, Ahern GP, Jackson MB: cGMP-mediated facilitation in nerve terminals by enhancement of the spike afterhyperpolarization. Neuron 2001;31:1015-1025.
40 Alborch E, Salom JB, Torregrosa G: Calcium channels in cerebral arteries. Pharmacol Ther 1995;68:1-34.

41 Striessnig J, Grabner M, Mitterdorfer J, Hering S, Sinnegger MJ, Glossmann $\mathrm{H}$ : Structural basis of drug binding to $\mathrm{L} \mathrm{Ca}^{2+}$ channels. Trends Pharmacol Sci 1998;19: 108-115.

42 Kang M, Ross GR, Akbarali HI: COOH-terminal association of human smooth muscle calcium channel $\mathrm{Ca}_{\mathrm{V}} 1.2 \mathrm{~b}$ with $\mathrm{Src}$ kinase protein binding domains: effect of nitrotyrosylation. Am J Physiol Cell Physiol 2007;293: C1983-C1990.

43 Sanders KM: Invited review: mechanisms of calcium handling in smooth muscles. J Appl Physiol 2001;91:1438-1449.

44 Lee CH, Poburko D, Kuo KH, Seow CY, van Breemen C: $\mathrm{Ca}^{2+}$ oscillations, gradients, and homeostasis in vascular smooth muscle. Am J Physiol Heart Circ Physiol 2002;282: H1571-H1583. 